\title{
A Case Report: Metastasis of Clear Cell Ovarian Cancer in Morrison's Pouch as Differential Diagnosis to Exophytic Kidney Tumor
}

\author{
Stine Lohmann ${ }^{*}$, Anna Krarup Keller ${ }^{2}$ \\ ${ }^{1}$ Department of Urology, Regional Hospital West, Holstebro, Denmark \\ ${ }^{2}$ Department of Urology, Aarhus University Hospital, Aarhus, Denmark \\ Email: *stiloh@rm.dk
}

How to cite this paper: Lohmann, S. and Keller, A.K. (2016) A Case Report: Metastasis of Clear Cell Ovarian Cancer in Morrison's Pouch as Differential Diagnosis to Exophytic Kidney Tumor. Open Journal of Uro$\log$, 6, 173-177.

http://dx.doi.org/10.4236/oju.2016.611028

Received: September 10, 2016

Accepted: November 14, 2016

Published: November 17, 2016

Copyright $\odot 2016$ by authors and Scientific Research Publishing Inc. This work is licensed under the Creative Commons Attribution International License (CC BY 4.0).

http://creativecommons.org/licenses/by/4.0/ (c) (i) Open Access

\begin{abstract}
A 62-year-old woman with a history of curatively treated mucinous ovarian cancer, presented with dyspnea, anorexia and right-upper-quadrant pain at consultation with her general practitioner. A CT scan revealed several lymph node metastases in lungs and abdomen as well as a tumor in Morrison's pouch and biopsy revealed renal cell carcinoma. Therefore, she was referred to Department of Urology. The multidisciplinary team could not immediately reject that there could be an exophytic tumor in the right kidney but discrepancy between histology and imaging, led to several biopsies including laparoscopic procedure. Re-examination of the primary ovarian cancer showed that one percent was classified as clear cell carcinoma. The final diagnose was metastatic clear cell ovarian carcinoma. The patient was terminal and suffered of cachexia and pleural effusion. The patient deceased four months after first consultation.
\end{abstract}

\section{Keywords}

Ovarian Cancer, Clear Cell Adenocarcinoma, Renal Cell Cancer, Immunohistochemistry

\section{Introduction}

Incidence of new ovarian cancer in Europe in 2012 is estimated to 65,538 [1] and for kidney cancer 43,435 (women) [2]. There is variation in the incidence rate across the continent with a higher incidence of ovary cancer in northern European countries, with Denmark having the second highest in the world [3].

Ovarian cancer often has no symptoms at the early stages, so the disease is generally 
advanced when it is diagnosed and therefore it has a poor prognosis [4]. Symptoms can be abdominal pain, urinary symptoms, constipation and abdominal swelling with weight loss. Furthermore, these patients have a lower rate of survival relative to many other cancer disease sites. An estimated 70\% - 75\% of patients will experience a recurrence [5] with a median time to recurrence of 18 - 24 months [6].

The most common type of kidney cancer is clear cell renal carcinoma [7] which accounts for $75 \%-90 \%$ of all cases. Clear cell adenocarcinoma of the ovary is less common, about $3 \%-10 \%$ [8]. It classifies as a so-called Type 1, like mucinous carcinomas, which are slow growing tumors and often diagnosed in lowest stadium I, despite of the frequently large size. Clear cell carcinoma of the ovary is per definition highly malignant and has a worse prognosis compared to other cell types [9].

Here we report on a patient with metastatic clear cell ovarian cancer years after intended curative treatment.

\section{Patient Presentation}

A 62 years old woman, with a history of ovarian cancer, was referred from the local Diagnostic Center with renal cell carcinoma, histological verified.

The patient was diagnosed with left-sided ovary cancer and classified as $1 \mathrm{~A}$ mucinous adenocarcinoma in 2012. At this time serum Ca-125 was 17. The patient underwent curative surgery with hysterectomy, bilateral salpingo-oophorectomy and omentectomy. The removed lymph nodes were without metastases and therefore no adjuvant chemotherapy was given. Subsequent controls were without relapse the following years.

The patient had in spring 2016 consulted her general practitioner (GP) because of dyspnea the last two months, newly anorexia and weight loss and upper right abdominal pain with radiation to the back. This was just four months after the last control at the department of gynaecology. The GP ordered x-ray of the lungs and ultrasound of abdomen. Because of a tumor suspect process, the radiologist added a CT thorax and abdomen and found several suspicious lymph nodes in both lungs and abdomen. More importantly, the scan detected a large tumor in Morrison's pouch (see Figure 1). Serum CA-125 was normal. Several biopsies failed and did not deliver sufficient material for histological analysis and a CT-guided biopsy revealed renal cell carcinoma.

Diagnosing renal cell carcinoma was a bit surprising, but the multidisciplinary team could not immediately reject, that there could be an exophytic tumor in the right kidney. Needing better histological material led to a laparoscopic excision of some of the tumor in Morrison's pouch. This time it showed adenocarcinoma but could not be differentiated furthermore.

At this time, the patient was hospitalized at Department of Urology because of progressive dyspnea and significant edema of the lower limbs. A CT scan of the lungs showed pleural effusion and the patient underwent bilateral tube thoracostomy, which improved respiration. Cytology demonstrated a few days later malignant cells. Additionally, CA-125 had risen to 223 during the four months that had passed since first consultation at the patients GP. 


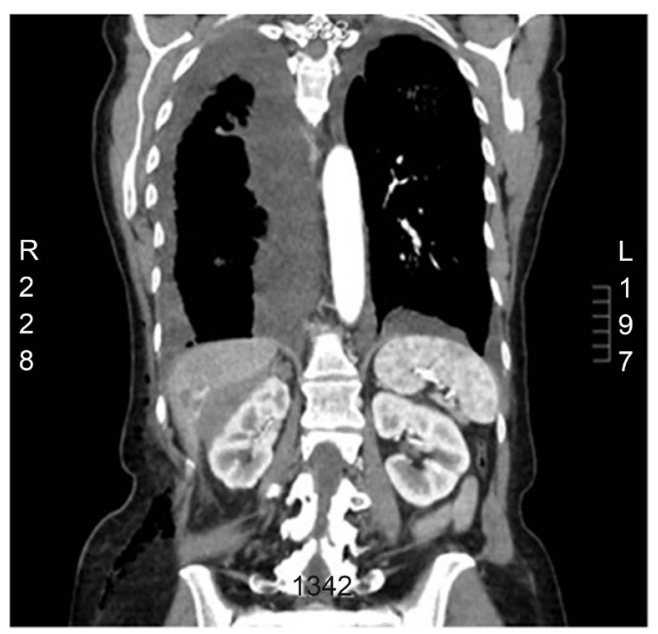

Figure 1. CT scan of right kidney and tumor in Morrison's pouch.

Pathological diagnosis was uncertain and material was therefore sent to Aarhus University Hospital for a second opinion. Here, the pathologists went through the patients previous tissue samples; the ovarian cancer from 2012 consisted of $1 \%$ clear cell ovarian carcinoma. Followed by immunohistochemically staining of the present tissue from Morrison's pouch confirmed that the latter was metastasis from the clear cell ovarian cancer.

The patient never received any additional treatment. The patient stayed hospitalized several weeks because of the difficult management of the pleural effusion. Furthermore, there was provided prophylactic antibiotics to avoid pneumonia, although blood sample showed normal infection level. Furthermore, the patient suffered of severe cachexia and transferred to hospice and died three weeks later. The final pathological diagnosis came but just one day ante mortem.

\section{Discussion}

This patient had difficult diagnostic challenges for several reasons. First, the tumor had close relation to the right kidney. From the CT scan the kidney appeared to be well defined and without irregularities but as mentioned it is difficult to contradict histological analysis. Second, the morphology for clear cell renal cell carcinoma is not unique and makes it challenging to distinguish between other clear cell variants.

By immunohistochemically staining, renal cell carcinoma is positive for CD10 and renal cell carcinoma monoclonal antibody (RCCma), while being negative for Ca-125. Nevertheless it has been suggested, that PAX2 and PAX8 are more stable markers. Unfortunately, they are both also positive regarding clear cell from the ovary [10]. This patient was amongst others negative for estrogen, Ca-125, CD10 and PAX8.

Renal cell carcinoma metastasize locally to vena renalis et cava and perirenal as well as hematogenous dissemination to liver, lungs and bone [7]. By hematogenous dissemination, the cells go through several steps of both intra- and extravasation before it can metastasize to other organs. The biology of ovarian carcinoma differs from that of 
hematogenously metastasizing tumors because ovarian cancer cells primarily disseminate within the peritoneal cavity-the peritoneum and omentum, but occasionally there can be lymphogenous involvement-primarily paraaortic [11].

Regarding survival of type 1 ovarian cancer, mucinous cancers have a better prognosis compared to clear cell [3]. Never the less it has not been possible to reduce mortality in clear cell stadium IA-IB by giving adjuvant chemotherapy and it is therefore not recommended in Denmark [3]. Overall, diagnosed ovarian cancer often reveals an advanced stage with metastasis and is therefore associated with high mortality. Dissemination is believed to involve less steps, because only a single cell or a group of cancer cells will have to release from the primary tumor. The transportation of cells is passive mechanism by movement of the peritoneal fluid, which gives multiple possibilities of sites for metastasis [11].

Immunohistochemical staining are our reliable way to make histological diagnoses, but in this case, the patient's primary histology was reassessed for clarification.

\section{Conclusion}

In conclusion, metastasis of previous cancer is of great importance in differential diagnosis. One should consider it a likely diagnosis even though primary cancer was of lower TNM and completed curative treatment.

\section{References}

[1] Ovary, EUCAN Cancer Factsheets. http://eco.iarc.fr/eucan/CancerOne.aspx?Cancer=27\&Gender=2\#block-map-f

[2] Kidney, EUCAN Cancer Factsheets. http://eco.iarc.fr/eucan/CancerOne.aspx?Cancer $=27 \&$ Gender $=2$

[3] DGCG (2016) Clinical Guideline for Visitation, Diagnostik, Treatment and Control of Epithelian Ovary-, Tuba- and Primary Peritoneal Cancer including Borderline Tumors. Udgave.

[4] Jacobs, I.J., Menon, U., Ryan, A., Gentry-Maharaj, A., Burnell, M., Kalsi, J.K., et al. (2016) Ovarian Cancer Screening and Mortality in the UK. Lancet, 387, 945-956. https:/doi.org/10.1016/S0140-6736(15)01224-6

[5] Ozga, M., Aghajanian, C., Myers-Virtue, S., McDonnell, G., Jhanwar, S., Hichenberg, S., et al. (2015) A Systematic Review of Ovarian Cancer and Fear of Recurrence. Palliative \& Supportive Care, 13, 1771-1780. https:/doi.org/10.1017/S1478951515000127

[6] Ushijima, K. (2010) Treatment for Recurrent Ovarian Cancer-At First Relapse. Journal of Oncology, 2010, Article ID: 497429. https:/doi.org/10.1155/2010/497429

[7] Ljungberg, B., Cowan, N.C., Hanbury, D.C., et al. (2010) EAU Guidelines on Renal Cell Carcinoma: The 2010 Update. European Urology, 58, 398-406. https:/doi.org/10.1016/j.eururo.2010.06.032

[8] Sugiyama, T., Kamura, T., Kigawa, J., Terakawa, N., Kikuchi, Y., Kita, T., Suzuki, M., Sato, I. and Taguchi, K. (2000) Clinical Characteristics of Clear Cell Carcinoma. A Distinct Histologic Type with Poor Prognosis and Resistance to Platinum Based. Cancer, 88, 2584-2589. https:/doi.org/10.1002/1097-0142(20000601)88:11<2584::AID-CNCR22>3.0.CO;2-5

[9] Heintz, A.P., Odicino, F., Maisonneuve, P., et al. (2006) FIGO 26th Annual Report on the 
Results of Treatment in Gynecological Cancer. International Journal of Gynecology \& Obstetrics, 95, S161-S192. https:/doi.org/10.1016/S0020-7292(06)60033-7

[10] Mentrikoski, M.J., Wendroth, S.M. and Wick, M.R. (2014) Immunohistochemical Distinction of Renal Cell Carcinoma from Other Carcinomas with Clear-Cell Histomorphology: Utility of CD10 and CA-125 in Addition to PAX-2, PAX-8, RCCma, and Adipophilin. Applied Immunohistochemistry \& Molecular Morphology, 22, 635-641.

https:/doi.org/10.1097/PAI.0000000000000004

[11] Lengyel, E. (2010) Ovarian Cancer Development and Metastasis. American Journal of Pathology, 177, 1053-1064. https:/doi.org/10.2353/ajpath.2010.100105

Submit or recommend next manuscript to SCIRP and we will provide best service for you:

Accepting pre-submission inquiries through Email, Facebook, LinkedIn, Twitter, etc. A wide selection of journals (inclusive of 9 subjects, more than 200 journals)

Providing 24-hour high-quality service

User-friendly online submission system

Fair and swift peer-review system

Efficient typesetting and proofreading procedure

Display of the result of downloads and visits, as well as the number of cited articles

Maximum dissemination of your research work

Submit your manuscript at: http://papersubmission.scirp.org/

Or contact oju@scirp.org 